\title{
THE IMPLEMENTATION OF LILIFUK CUSTOMARY LAW TOWARDS COASTAL ENVIRONMENTAL DEGRADATION OF KUPANG BAY
}

\author{
Ranny Unbanunaek, Jimmy Pello, Karolus Kopong Medan \\ Law Graduate Program Universitas Nusa Cendana \\ E-mail: adeun1312@gmail.com
}

\begin{abstract}
The kuanheun coastal communities have a customary law that help maintain coastal environmental sustainability resources called as lilifuk customary law(lilifuk atolan instrument). This research applied empirical method by formulating three problems: what are the values embedded in lilifuk customary law; how is the of lilifuk customary law contribution to prevent coastal environmental degradation; and how is the correlation between lilifuk customary law values and the law provision on coastal areas and small islands management. The result of the research identified the following; the first, Lilifuk customary law contains religious value, ecological value, communal value, social relations value, solidarity and responsibility value, social leadership value, and educational value. Second, the settlement of law violation by lilifuk customary law is conduted by the following steps: reporting; discussion; verdict; and execution. Third, there is a correlation between the lilifuk customary lilifuk values and WP3K Law values.
\end{abstract}

Keywords: lilifuk customary law, environmental degradation, kupang bay

\begin{abstract}
Abstrak
Masyarakat pesisir Desa Kuanheun memiliki hukum adat yang membantu menjaga kelestarian lingkungan dan sumber daya pesisir, yakni hukum adat lilifuk (atolan alat lilifuk). Penelitian ini menggunakan metode penelitian empiris dengan tiga permasalahan, yaitu: nilai-nilai apasajakah yang terkandung dalam hukum adat lilifuk; bagaimanakah peranan hukum adat lilifuk dalam mencegah perusakan lingkungan pesisir; bagaimanakah keterkaitan antara nilai-nilai hukum adat lilifuk dengan ketentuan Undang-Undang Pengelolaan Wilayah Pesisir dan Pulau-pulau Kecil. Berdasarkan penelitian ditemukan bahwa pertama, Hukum adat lilifuk mengandung nilai-nilai, di antaranya: nilai religius, nilai ekologi, nilai komunal, nilai relasi sosial, nilai solidaritas dan tanggung jawab, nilai kepemimpinan sosial, dan nilai pendidikan. Kedua, penyelesaian terhadap pelanggaran hukum ada lilifuk akan ditempuh melalui tahap-tahap sebagai berikut: Pelaporan; Perundingan; Putusan; dan Eksekusi. Ketiga, Ada keterkaitan antara nilai-nilai yang terkandung dalam hukum adat lilifuk dengan nilai-nilai dalam UU WP3K.
\end{abstract}

Kata kunci: hukum adat lilifuk, perusakan lingkungan, teluk kupang.

\section{Introduction}

The development of Kupang Bay coastal region increases. This brings a bad effect for the coastal environment because it is still dominated by economic interests. In the last few years the region has experienced a significant change by the buildings and the hospitality industrial estab-

$\Omega$ This Journal is summarized from Thesis with the same title based on Decree Dean No: 070/18/KCKB/2016 lishments including stores and restaurant. The buildings are built right in the coastal areas which cause coastal reclamation. Besides the activities of people around the coastal region also made great contributions to the environmental damage in coastal areas. One of that activities is non ecofriendly fishing. Based on research conducted by Jimmy Pello and Peter Kase in 2015 in Kupang Bay areas, it was found that the threat of the destruction of coral reefs in Kupang Bay coastal 
areas caused by the activities of the infrastructure development, coral mining, sea sand exploitation, waste disposal, fish bombing, cyanidepoisoned fishing, makameting activity by nearby community, and the mangroves cut off. ${ }^{1}$

Management of coastal areas requires the cooperation of various parties, both government and private sectors including the public especially those coastal communities who play a major role as the closest party to the coastal region itself. Coastal communities can provide real support to the sustainable coastal areas management. People in Kupang Bay coastal areas have customary laws that can support the sustainability of the natural resources in the coastal areas namely lilifuk customary law (atolan alat lilifuk) applied in coastal areas of Kuanheun Village, West Kupang District, Kupang. Lilifuk customary law is an ecofriendly fishing culture by considering coastal ecosystems and the biota sustainability.

\section{Problems}

Based on the background, the problems can be formulated as follows: first, what are the values of Lilifuk Customary Law?; second, how is the contribution of Lilifuk Customary Law to prevent coastal environmental degradation?; and third, how is the correlation between the values of Lilifuk Customary Law and the provisions of the WP3K Law?

\section{Research Methods}

This is a juridical empirical legal research. Empirical legal or socio-legal research in this study, not only see law as prescriptive discipline and the application, but also empirical or fact of law. ${ }^{2}$ This empirical juridical research focuses on

Jimmy Pello and Petrus Kase, 2015, Konflik Pemerintah Daerah dalam Mengatasi Konflik Penduduk Pesisir dengan Satwa Liar Berbahaya di Teluk Kupang, Laporan Penelitian, Kupang: Doctor Program Study of Administration Science Universitas Nusa Cendana, page 33.

2 Depri Liber Sonata, "Metode Penelitian Hukum Normatif dan Empiris: Karakteristik Khas dari Metode Meneliti Hukum", Jurnal Fiat Justisia, Vol. 8 No. 1. Januari-March the study of legal identification, ${ }^{3}$ i.e., research which aims to know the law based on the applicable law in the society. Primary data in this study were obtained from Focus Group Discussion (FGD). Then the data were analyzed using qualitative descriptive juridical method to provide an understanding of research data.

\section{Discussion}

\section{The values of Lilifuk Customary Law}

Local wisdom is a way of life and science as well as various life strategies in the form of activities undertaken by local communities in addressing various problems in daily basis. In general, it is called as local wisdom, local knowledge or local genious. ${ }^{4}$ Local wisdom, generally includes all elements of human culture which includes religious system, language, economic, technology, education, social organizations, and arts. Local knowledge is initially derived from the idea or thoughts and is then applied in practice, and the creation of material culture. ${ }^{5}$

Customary law is an unwritten rule that live in indigenous people in particular area and will remain as long as people still obey the customary law passed down over generations. ${ }^{6}$ In addition, according to Moh Koesnoe, customary law is a law model of Malays ethnic community as an ethnic group legal doctrine of a nation. ${ }^{7}$

2014, Lampung: Faculty of Law Universitas Lampung, page 29.

3 Soejono dan Abdurrahman, 2003, "Metode Penelitian Hukum, Jakarta: Rineka Cipta, page 55.

4 Ulfah Fajarini, "Peranan Kearifan Lokal dalam Pendidikan Karakter", Jurnal Sosio Didaktika, Vol. 1 No. 2, December 2014, Jakarta: Universitas Islam Negeri (UIN) Syarif Hidayatullah, page 123-124.

5 Christeward Alus, "Peran Lembaga Adat dalam Pelestarian Kearifan Lokal Suku Sahu di Desa Balisoan Kecamatan Sahu Kabupaten Halmahera Barat, Journal Acta Diurna. Vol. III No. 4, 2014, Manado: Universitas Sam Ratulangi, page 1.

6 Marco Manarisip, "Eksistensi Pidana Adat dalam Hukum Nasional”, Jurnal Lex Crimen, Vol. I No. 4, OctoberDecember 2012, Manado: Universitas Sam Ratulangi, page 24.

7 Reny H. Nendiss, "Eksistensi Lembaga Adat dalam Pelaksanaan Hukum Sasi Laut di Maluku Tengah, Jurnal Sasi, Vol. 16 No. 4 October-December 2010 Edition, page 1 
Lilifuk $^{8}$ is a basin at the bottom of coastal waters at highest tide. This basin area will resemble a large pool with a maximum depth of 5 (five) meters and a width reaches $\pm 20,000$ (twenty thousand) $\mathrm{m}^{2}$. When the tide is low, lilifuk will be filled with a variety of marine life trapped in it. Provisions of lilifuk management are made by the Baineo tribe as landlords (pah tuaf) or the owner of lilifuk which cover: first, lilifuk harvest is done once a year in December, known as the "tut nifu"; second, when the harvest comes, people are obliged to invite the whole village and the neighboring villages; third, anyone is prohibited to enter or take marine life in the region lilifuk other than the harvest time; fourth, at harvest time, everyone is obliged to use fishing gear that does not destroy lilifuk; fifth, everyone who attends the crops is obliged to give tribute to the Baineo tribe in the form fish from their catch. The tribute is known as the "tanaib $i k a "$ " which means "cutting fish harvest"; and sixth, any person who violates the provisions of Baineo tribes will be imposed sanctions, namely fines (Opat) in the form of a pig (fafi).

In doing so, there are 7 (seven) values of lilifuk customary law. First, Religious Values. Kuanheun society believed in the power that ruled the sea called the King of the Sea (Uis Tasi). It can be found in the myths believed, that if someone violates lilifuk customary law (Atolan alat lilifuk), such as fishing prematurely, then that person is believed to be bad luck. Second, the Ecological value. Lilifuk customary law stipulates that in fishing, everyone is required to use gear that does not destroy lilifuk, stated in customary expression: "het ika at Paek at pake bale le kana leu tasi" means to catch fish using a tool that does not damage the sea. Lilifuk customary law (Atolan alat lilifuk) intended to maintain their coastal environment. Third, Communal value. As the landlord (pah tuaf) of lilifuk, Baineo tribe do not intend to posses lilifuk abso-

8 Word lilifuk comes from Dawan language (Timor Tribe Languange), namely word "nifu" means pool. lutely. Instead, the results and benefits of lilifuk become the property of every resident of the Kuanheun village. Although the Baineo tribe have a strong relationship with lilifuk as landowners but this should not weaken the joint ownership of lilifuk benefits. Additionally, to resolve any lilifuk infringement, it must be done by consensus involving various stakeholders and the public.

Fourth, Social Relations Value. Lilifuk customary law (Atolan alat lilifuk) gives an overview of how man should build a good, harmonious, balanced social relation among them, and human with his environment. This law seeks to create a good relationship between the community through the provision of an invitation to harvest and deliberations conducted in resolving all matters. Not only human relations, Lilifuk customary law (Atolan alat lilifuk) also strives to create a good relationship between human and the environment by maintaining and trying to preserve it. There was an awareness that the environment as part of their life had an attachment to one another that must always be maintained. Fifth, Solidarity and Responsibilities Values. Conservation efforts through Lilifuk customary law show their sense of responsibility and solidarity of Kuanheun society on the marine life and environmental sustainability. The community shows their responsibility by keeping them from extinction and from exploiting parties. Sixth, Social Leadership Values. Recognition and appreciation of indigenous leader are found in Lilifuk customary law. Indigenous leaders, such as the traditional institutions (amnais alat), the village head (temukung), landlords (pah tuaf), and amnasit play a central role in resolving problems and indigenous rituals. The society obey any decisions made by indigenous leaders. Every decision made by the leader will be followed by the public as truth. The role and tasks performed by their leaders have built a sense of leadership in the community. Leadership values is also shown by the people attitude if people want to do something in the region of landlords, they will ask for permission from the 
landlord as their leader by expressing ("a etun auf tuaf" means "tell the landlord"). Seventh, Education Values. Lilifuk customary law (Atolan alat lilifuk) functions as learning media including ecological, communal (togetherness), solidarity and responsibility, social relations and the social leadership. Lilifuk customary law (Atolan alat lilifuk) taught the importance of preserving the environment and how humans should establish good relations and harmony with each other and the environment.

Role of Lilifuk Customary Law in Preventing Kupang Bay Coast Environmental Degradation

Lilifuk customary law (Atolan alat lilifuk) recognizes several prohibitions. First, it is prohibited to use destructive fishing tool in lilifuk (kais taleu talas); second, it is prohibited to catch fish other than harvest time (at panen an mui oras); third, it is not allowed to take turtles (kaisat het hek ke); fourth, it is not allowed to exploit sea sand and stones (kais taitis snaen); fifth, it is forbidden to pollute the sea (kais taleu tasi); sixth, it is forbidden spoil the salt drying (kais taleu atoni in masi).

There are several stages to take to improve the violated law, customary violations. The process of settling criminal cases through the customary judicial forum is basically aimed at creating a resolution between the parties involved in criminal cases, both as perpetrators and victims in an atmosphere of brotherhood. ${ }^{9}$ Customary institutions have the authority to resolve any problem based on customary law prevailing in the society $^{10}$ including Kuanheun Society. Customary institution is a community organization that is deliberately formed or have grown and evolved in the history of the community or in a certain cus-

9 Karolus Kopong Medan, "Peradilan Berbasis Harmoni dalam Guyub Budaya Lamaholot-Flores", Jurnal Dinamika Hukum, Vol. 12 No. 2, May 2012, Kupang: Faculty of Law Universitas Nusa Cendana, page 210.

10 Kamaruddin, and friends, "Model Penyelesaian Konflik di Lembaga Adat”, Jurnal Walisongo, Vol. 21 No. 1, May 2013, Aceh: IAIN Ar-Raniry, page 59. tomary law society with jurisdiction and rights on properties within the area of customary law. ${ }^{11}$

The stages of dispute settlement known as ator sinlasi are explained as follows: first, Reporting (Mu ota lasi or tatek oko mama). If any dispute or customary violation occur, initially it will be reported to the village head (temukung), traditional institutions (amnais alat), chieftain Baineo or amnasit. The report can be made by the victim, the perpetrator (asanat) and others. The reporting process is known as "mu ota lasi" which means "telling the problems/violations". This process can also be referred to as "tatek oko mama" which means "bring/sat the betel nut" if the report violations of the customs were made by the perpetrators themselves. Generaaly they would admit their guily as they report it and express their apology which is symbolized by bringing betel nut (oko mama). Second, Negotiations (Tok ta bua).After receiving the report, all concerned parties will conduct negotiations known as "tok ta bua", which means "sit together". In these negotiations, they will conduct deliberations to determine the customary sanction that will be imposed by listening to witnesses. In determining the sanction, any negotiating parties will pay attention to the ability of the offender, whether the offender can meet traditional sanctions given or not. Third, Verdict (Tafek lasi). After the verdict traditional sanctions have been determined in negotiations, it will be delivered to the perpetrator dealing with the sanction preceded by the provision of advice and guidelines to live by one of the parties that have been designated. After giving advice to the guilt, it will be delivered the verdict on traditional sanctions given. In customary law, traditional sanctions usually imposed is fine (Opat). Fourth, Execution (Ta naoba fekat). The execution is initiated by the slaughter of animals brought by the perpetrator. Animals that

11 Ayu Mukhtaromi, et.all, "Sinergi Pemerintah Daerah dan Lembaga Adat dalam Melaksanakan Pelestarian Kebudayaan”, Jurnal Administrasi Publik (JAP), Vol. 1 No. 2, Malang: Faculty of Administration Science Universitas Brawijaya, page 158 . 
have been slaughtered will be cooked and then will be shared by the traditional institutions (amnais alat), the village head (temukung), amnasit, actors (asanat), and also the people (toh). The process of eating together is also a symbol of their binding to the customary law provisions, especially for the offender to return to bind himself to the customary law that have been infringed so that in the future has no longer in violation. This process will also clean the perpetrators from consequences (bad luck) and misdeeds law and improve his relations with the community after the violation.

The Correlation between Lilifuk customary law Values and the Provisions of Coastal Areas and Small Islands Management Law

\section{Ecological values}

WP3K Law governs coastal areas and small islands management to protect, conserve, rehabilitate, utilize, and enrich resources and ecological systems.

\section{Communal Values}

WP3K Law provides an opportunity of coastal areas and small islands utilization to the various sectors through the issue of location and management license. It also provides the opportunity to various stakeholders and the public in terms of a variety of coastal management plans.

\section{Social Relations Values}

WP3K Law strives to build good relationships between the various parties in order to protect the environment by integrating the activities between central and regional governments, interlocal government, among governments, business, and society, among terrestrial ecosystems and the marine ecosystem, as well as science and management principles.

\section{Solidarity and Responsibilities Values}

The government showed its solidarity to the community by empowering the community by providing facilities, encouragement or assistance to communities and local fishermen to be able to determine the best option in coastal resources utilization. The responsibility is performed with the rehabilitation that must be done by the government and/or regional governments and/or the individual who take direct and indirect benefit from the coastal environment.

Social Leadership Values

Any one who wants to take advantage of coastal areas is required to have a location and management license granted by the government. In particular, the government acts as a leader or higher-level administratives.

\section{Educational Values}

Utilization of coastal areas and small islands is also an advantage to the field of education and training, also research and development of science related to the field of coastal environments can be conducted by the government, local governments, universities, non-governmental organizations, research institutions and private developers or individual. The government will typically also hold education, training and extensive management of coastal areas in order to improve the development of human resources in coastal management.

To put it in brief, it can be seen that there is a correlation between the Lilifuk customary law (Atolan alat lilifuk) values and in the WP3K Law values. The values in lilifuk customary law (Atolan alat lilifuk) is in accordance with the WP3K Law. The similarity of shared values manifested in norms that are relatively similar in essence. In other words, both rules concern the coastal environment management running side by side who support each other.

\section{Conclusion}

The values embodied in Lilifuk customary law are: religious values, ecological values, communal values, the social relations value, solidarity and responsibility, social leadership, and education. These values are embodied in Lilifuk customary law.

If any environmental degradation cases occur, the Lilifuk customary law (Atolan alat 
lilifuk) will play a role in resolving the issue. The stage of problem settlement can be described as follows: Reporting (mu ota lasi or tatek oko mama), negotiations (tok ta bua), Verdict (tafek lasi), and Execution (ta naoba fekat).

There is a close relationship between the values embodied in Lilifuk customary law (Atolan alat lilifuk) with values in the WP3K Law. Both norms contain similar values so it can work together in maintaining and preserving the coastal environment.

\section{Suggestion}

The government is expected to give more attention to the customary law and local wisdom that has lasted for a long time in the community. The government is expected to manage which brings positive impact to the community to improve a sense of belonging of coastal areas to the public.

The coastal communities are expected to be aware and play their role as the first line of the coastal environment guard. Customary law communities and the people who have local knowledge on environmental management and sustainability are expected to maintain the culture that has been practiced for generations. The general public is expected to provide care to the environment to sustain the ecosystem. By keeping the same neighborhood by keeping the house and barns on our own, good environment will provide a good benefit for us.

\section{References}

Alus, Christeward. "Peran Lembaga Adat dalam Pelestarian Kearifan Lokal Suku Sahu di Desa Balisoan Kecamatan Sahu Kabupaten Halmahera Barat. Journal Acta Diurna. Vol. III No. 4. 2014. Manado: Communication Science-Faculty of Sociasl and Political Science Universitas Sam Ratulangi;

Fajarini, Ulfah. "Peranan Kearifan Lokal dalam Pendidikan Karakter”. Jurnal Sosio Didaktika. Vol. 1 No. 2. December 2014. Jakarta: Universitas Islam Negeri (UIN) Syarif Hidayatullah;
Kamaruddin, dkk. "Model Penyelesaian Konflik di Lembaga Adat". Jurnal Walisongo. Vol. 21 No. 1. May 2013. Aceh: IAIN Ar-Raniry;

Manarisip, Marco. "Eksistensi Pidana Adat dalam Hukum Nasional”. Jurnal Lex Crimen. Vol. I No. 4. October-December 2012. Manado: Universitas Sam Ratulangi;

Medan, Karolus Kopong. "Peradilan Berbasis Harmoni dalam Guyub Budaya Lamaholot-Flores. Jurnal Dinamika Hukum. Vol. 12 No. 2. May 2012. Kupang: Faculty of Law Universitas Nusa Cendana;

Mukhtaromi, Ayu, dkk. "Sinergi Pemerintah Daerah dan Lembaga Adat dalam Melaksanakan Pelestarian Kebudayaan". Jurnal Administrasi Publik (JAP). Vol 1 No. 2. Malang: Faculty of Administrative Science Universitas Brawijaya;

Nendiss, Reny $H$. "Eksistensi Lembaga Adat dalam Pelaksanaan Hukum Sasi Laut di Maluku Tengah. Jurnal Sasi. Vol. 16 No. 4. OctoberDecember 2010. Ambon: Faculty of Law Universitas Pattimura;

Pello, Jimmy dan Petrus Kase. 2015. Konflik Pemerintah Daerah dalam Mengatasi Konflik Penduduk Pesisir dengan Satwa Liar Berbahaya di Teluk Kupang. Laporan Penelitian, Kupang: Doctor Program Study of Administration Science Universitas Nusa Cendana;

Soejono dan Abdurrahman. 2003. Metode Penelitian Hukum. Jakarta: Rineka Cipta;

Sonata, Depri Liber. "Metode Penelitian Hukum Normatif dan Empiris: Karakteristik Khas dari Metode Meneliti Hukum". Jurnal Fiat Justisia. Vol. 8 No. 1 January-March 2014 Edition. Lampung: Faculty of Law Universitas Lampung. 